\title{
Upaya Hukum Penyelesaian Sertipikat Hak Atas Tanah Ganda di Kota Yogyakarta
}

\author{
Beby Ista Pranoto ${ }^{1}$, Sunarno ${ }^{2}$ \\ ${ }^{1,2}$ Program Studi Hukum, Fakultas Hukum, Universitas Muhammadiyah Yogyakarta, Indonesia \\ E-mail: ${ }^{1}$ Beby.ista.2015@law.umy.ac.id, ${ }^{2}$ narno_muh@yahoo.com
}

\section{Info Artikel}

Diajukan: 04-08-2020

Direview: 18-08-2020

Direvisi: 24-08-2020

Diterima: 25-08-2020

DOI: $10.18196 / \mathrm{mls}$.v1i3.9500

\begin{abstract}
Abstrak
Sertipikat ganda merupakan sertipikat-sertipikat yang menguraikan satu bidang tanah yang sama dengan berlainan datanya. Hal semacam ini disebut pula "Sertipikat Tumpang Tindih", baik tumpang tindih seluruh bidang maupun tumpang tindih sebagian dari tanah tersebut. Tujuan penelitian ini adalah untuk mengetahui dan menganalisis penyelesaian, dan faktor-faktor yang menghambat dalam penyelesaian sertipikat hak atas tanah ganda di Kota Yogyakarta. Berdasarkan data
\end{abstract} yang diperoleh, dari hasil penelitian kepustakaan maupun penelitian lapangan, kemudian dianalisis dengan menggunakan metode deskriptif kualitatif, yaitu data yang diperoleh dilapangan maupun kepustakaan, disusun secara sistematis setelah diseleksi berdasarkan permasalahan dan dilihat kesesuaiannya dengan ketentuan yang berlaku, selanjutnya disimpulkan sehingga diperoleh jawaban atas permasalahan. Penyelesaian sertipikat hak atas tanah ganda di Kota Yogyakarta dilakukan dengan musyawarah, arbitrase dan alternative penyelesaian sengketa dan penyelesaian sengketa melalui badan peradilan. Faktor-faktor yang menghambat dalam penyelesaian sertipikat hak atas tanah ganda di Kota Yogyakarta yaitu kurangnya Mediator dalam Sengketa Tanah, pada Kantor Badan Pertanahan Nasional Kota Yogyakarta pada seksi-seksi tersebut di masing-masing Kantor Pertanahan Kabupaten/Kota belum ada yang memiliki sertifikasi sebagai mediator berlisensi, dan netralitas BPN sebagai mediator sering dipermasalahkan karena seringkali sengketa tanah yang terjadi antara para pihak di dalamnya melibatkan produk hukum yang dibuat oleh BPN.

Kata kunci: sengketa tanah; sertipikat ganda; sertipikat tumpang tindih

\section{Pendahuluan}

Hak-hak atas tanah mempuyai peranan penting dalam kehidupan manusia, makin maju masyarakat dan makin padat penduduknya, akan menambah lagi pentingnya kedudukan hak-hak atas tanah, dalam arti kata tanah mempuyai fungsi status sosial seseorang, oleh karena itu untuk pemilikan hak atas tanah haruslah didaftarkan guna untuk pembuktian secara yuridis. Tanah dikuasai oleh negara menurut penjelasan umum Undang-Undang Pokok Agraria (UUPA), bukanlah berarti dimiliki akan tetapi adalah pengertian memberi wewenang kepada negara, sebagai organisasi kekuasaan, untuk tingkat yang tertinggi, mengatur dan menyelenggarakan peruntukkan, penggunaan dan pemeliharaannya, mengatur dan menentukan hubungan-hubungan antara orang-orang dan perbuatan-perbuatan hukum mengenai bumi dan air. Dengan kekuasaan tersebut negara dapat memberikan tanah kepada seseorang atau badan hukum dengan sesuatu hak menurut keperluannya, misalnya hak milik, hak guna usaha, hak guna bangunan dan lainnya. 
Hak milik atas tanah adalah merupakan hak untuk mempertahankan, memperlakukan suatu hak atas tanah sebagai kepunyaannya sendiri, meliputi hak untuk memperoleh hasil sepenuhnya dari tanah dan untuk mempergunakan tanah itu sebagai miliknya, yang berarti ia sebagai pemilik dapat melakukan perbuatan hukum atas tanah tersebut. Namun demikian masalah pertanahan seperti keadaan sekarang ini semakin bertambah rumit, seperti yang terjadi dalam wilayah Kota Yogyakarta, di mana ada kecenderungan sengketa tanah harus diselesaikan melalui jalur hukum, baik melalui Peradilan Umum maupun melalui Peradilan Tata Usaha Negara. Hal ini dilakukan oleh pihak-pihak yang bersengketa untuk memperoleh kepastian hukum.

Berlakukannya Undang-Undang Nomor 5 Tahun 1986 sebagaimana telah dirubah dengan Undang-Undang Nomor 51 Tahun 2009 tentang Peradilan Tata Usaha Negara, ada kecenderungan sengketa masalah pertanahan diajukan pada Pengadilan Tata Usaha Negara setempat, dan sebagai objek sengketanya adalah Keputusan Kepala Kantor Pertanahan berupa penerbitan Sertipikat Hak Milik (SHM) atau penolakan penerbitan Sertipikat Hak Milik. Sertipikat Hak Milik (SHM) atas tanah berdasarkan Pasal 1 angka 3 Undang-Undang Nomor 51 Tahun 2009 adalah merupakan keputusan Pejabat Tata Usaha Negara, yang bersifat penetapan tertulis, konkret, individual dan bersifat final.

Penerbitan sertipikat tanah yang dilakukan oleh Kepala Kantor Pertanahan dapat saja terjadi adanya kesalahan dalam hal ukuran ataupun mengenai luas tanahnya yang mengakibatkan pihak yang memiliki Sertipikat Hak Milik merasa dirugikan atas terbitnya Sertipikat Hak Milik tersebut. Hal ini dapat saja dikarenakan kesalahan prosedural dalam proses pendaftaran tanah. Oleh karena itu pihak yang merasa dirugikan karena penerbitan Sertipikat Hak Milik atas tanah tersebut dapat mengajukan gugatan kepada Kepala Kantor Pertanahan di Pengadilan Tata Usaha Negara dan Kepala Kantor Pertanahan selaku Pejabat Tata Usaha Negara menerbitkan keputusan berupa Sertipikat Hak Milik dapat dimintakan pembatalan bilamana dari hasil pemeriksaan dipersidangan Pengadilan Tata Usaha Negara terbukti terbitnya sertipikat yang menjadi obyek sengketa benar-benar tidak prosedural sehingga mengakibatkan adanya kesalahan teknis. Dalam hal yang demikian, dapat saja muncul pihak lain (pihak ketiga) yang merasa mempunyai kepentingan dalam sengketa tersebut, yakni pihak yang juga merasa sebagai pemegang atau pemilik tanah atas obyek yang sama. Adanya sertipikat ganda yang berbeda kepemilikannya atas satu objek tanah ini dapat saja terjadi karena adanya kepentingan pihak tertentu untuk mengeruk keuntungan pribadi ataupun karena kesalahan prosedural.

Sertipikat ganda atas tanah adalah sertipikat yang diterbitkan oleh Badan Pertanahan Nasional (BPN) yang akibat adanya kesalahan pendataan pada saat melakukan pengukuran dan pemetaan pada tanah, sehingga terbitlah sertipikat ganda yang berdampak pada pendudukan tanah secara keseluruhan ataupun sebagaian tanah milik orang lain. Apabila ditinjau dari pengertian sertipikat itu sendiri maka sertipikat adalah tanda bukti hak atas tanah, yang dikeluarkan oleh pemerintah dalam rangka 
penyelenggaraan pendaftaran tanah menurut ketentuan peraturan dan perundangundangan.

Sertipikat hak atas tanah membuktikan bahwa seseorang atau suatu badan hukum, mempunyai suatu hak atas bidang tanah tertentu. Pada kenyataannya bahwa seseorang atau suatu badan hukum menguasai secara fisik dan menggunakan tanah yang bersangkutan tidak serta merta langsung membuktikan bahwa ia mempunyai hak atas tanah yang dimaksud. Adanya surat-surat jual beli, belum tentu membuktikan bahwa yang membeli benar-benar mempunyai hak atas tanah yang dibelinya. Apalagi tidak ada bukti otentik bahwa yang menjual memang berhak atas tanah yang dijualnya. Dalam konteks inilah terjadi pendudukan tanah secara tidak sah melalui alat bukti berupa dokumen (sertipikat) yang belum dapat dijamin kepastian hukumnya. Maksud gambaran diatas adalah suatu peristiwa penerbitan sertipikat ganda atas tanah, yang mengakibatkan adanya pemilikan bidang tanah atau pendudukan hak yang saling bertindihan satu dengan yang lain. A.P. Parlindungan menyatakan yang dimaksud dengan sertipikat ganda adalah surat keterangan kepemilikan (dokumen) dobel yang diterbitkan oleh Badan Hukum yang mengakibatkan adanya pendudukan hak yang saling bertindihan antara satu bagian atas sebagianyang lain. ${ }^{1}$

Sertipikat dobel/ganda adalah surat tanda bukti kepemilikan hak atas tanah yang diterbitkan oleh Lembaga Hukum (BPN) yang terbit diatas satu objek hak yang bertindih antara satu objek tanah sebagian atau keseluruhan, yang dapat terjadi suatu akibat hukum. ${ }^{2}$ Sertipikat ganda merupakan sertipikat-sertipikat yang menguraikan satu bidang tanah yang sama dengan berlainan datanya. Hal semacam ini disebut pula "Sertipikat Tumpang Tindih (overlapping)", baik tumpang tindih seluruh bidang maupun tumpang tindih sebagian dari tanah tersebut. Tidak termasuk dalam kategori sertipikat ganda, yaitu:

1. Sertipikat yang diterbitkan sebagai Pengganti Sertipikat yang hilang.

2. Sertipikat yang diterbitkan sebagai Pengganti Sertipikat yang rusak.

3. Sertipikat yang diterbitkan sebagai pengganti sertipikat yang dibatalkan. Hal ini disebabkan karena sertipikat-sertipikat dimaksud diatas telah dinyatakan dan tidak berlaku sebagai tanda bukti.

4. Sertipikat Hak Guna Bangunan diatas Hak Milik maupun diatas Hak Pengelolaan, karena menurut peraturan perundang-undangan yang berlaku, hal yang dimaksud memang dimungkinkan. ${ }^{3}$

Sertipikat ganda sering terjadi diwilayah-wilayah yang masih kosong, belum dibangun dan didaerah perbatasan kota dimana untuk lokasi tersebut belum ada peta-

\footnotetext{
${ }^{1}$ A.P. Parlindungan, Hilangnya Hak-hak Atas Tanah, CV. Mandar Maju, Bandung, 1999, hlm. 113.

${ }^{2}$ Kartasaputra, Masalah Pertanahan di Indonesia, Rineka Cipta, Jakarta, 2005, hlm. 120.

3 Ali Achmad Chomzah, Hukum Pertanahan; Pemberian Hak Atas Tanah Negara, Sertipikat Dan Permasalahan, Prestasi Pustaka, Jakarta, 2002, hlm. 139.
} 
peta pendaftaran tanahnya. Sertipikat ganda dapat terjadi karena beberapa hal sebagai berikut:

1. Pada waktu dilakukan pengukuran ataupun penelitian dilapangan, pemohon dengan sengaja atau tidak sengaja menunjukkan letak tanah dan batas-batas yang salah.

2. Adanya surat bukti atau pengakuan hak dibelakang hari terbukti mengandung ketidakbenaran, kepalsuan atau sudah tidak berlaku lagi.

3. Untuk wilayah yang bersangkutan belum tersedia Peta Pendaftaran Tanahnya.

4. Kasus penerbitan lebih dari satu sertipikat atas sebidang tanah dapat pula terjadi atas tanah warisan. Latar belakang kasus tersebut adalah sengketa harta warisan yaitu oleh pemilik sebelum meninggalnya telah dijual kepada pihak lain (tidak diketahui oleh anak-anaknya) dan telah diterbitkan sertipikat atas nama pembeli, dan kemudian para ahli warisnya mensertipikatkan tanah yang sama, sehingga mengakibatkan terjadi sertipikat ganda, karena sertipikat terdahulu ternyata belum dipetakan. ${ }^{4}$

Bertitik tolak dari uraian tersebut di atas maka penulis merasa tertarik untuk menuangkannya dalam dalam bentuk tulisan ilmiah dengan judul "Analisis Yuridis Penyelesaian Sertipikat Hak Atas Tanah Ganda Di Kota Yogyakarta". Berdasar uraian di atas masalah yang dikaji adalah 1) penyelesaian sertipikat hak atas tanah ganda di Kota Yogyakarta?, dan 2) faktor-faktor yang menghambat dalam penyelesaian sertipikat hak atas tanah ganda di Kota Yogyakarta?

\section{Metode}

Metode penelitian yang digunakan mengunakan metode penelitian hukum empiris yang menggunakan data primer yang didukung dengan penelitian kepustakaan sebagai data sekunder. ${ }^{5}$ Dengan menggunakan pendekatan yuridis, data yang diperoleh dari penelitian, baik dari penelitian kepustakaan maupun penelitian lapangan, kemudian dianalisis dengan menggunakan metode deskriptif kualitatif, yaitu data yang diperoleh dilapangan maupun kepustakaan, disusun secara sistematis setelah diseleksi berdasarkan permasalahan dan dilihat kesesuaiannya dengan ketentuan yang berlaku, selanjutnya disimpulkan sehingga diperoleh jawaban atas permasalahan.

\section{Hasil dan Pembahasan}

\subsection{Penyelesaian Sertipikat Hak Atas Tanah Ganda}

Badan Pertanahan Nasional (BPN) adalah Lembaga Pemerintah Non Kementerian yang berada di bawah dan bertanggung jawab kepada Presiden dan dipimpin oleh

\footnotetext{
${ }^{4}$ Eddy Ruchiyat, Sistem Pendaftaran Tanah Sebelum dan Sesudah Berlakunya UUPA, Armico, Bandung, 1984, hlm. 131.

${ }^{5}$ Ronny Hanitijo Soemitro, Metodologi Penelitian Hukum, Ghalia Indonesia, Jakarta, 1985, hlm. 24.
} 
Kepala. Badan Pertanahan Nasional mempunyai tugas melaksanakan tugas pemerintahan di bidang pertanahan secara nasional, regional dan sektoral sesuai dengan ketentuan peraturan perundang-undangan.

Badan Pertanahan berfungsi untuk menyelenggarakan merumuskan Kebijaksanaan dan Perencanaan Penguasaan dan Penggunaan Tanah, merumuskan Kebijaksanaan dan Perencanaan Pengaturan Pemilikan Tanah dengan prinsip-prinsip bahwa tanah mempunyai fungsi sosial sebagaimana diatur dalam UUPA, melakukan Pengukuran dan Pemetaan serta Pendaftaran Tanah dalam upaya memberikan kepastian hak dibidang Pertanahan. Dalam aturannya, dasar pembentukan BPN adalah Keputusan Presiden Nomor 26 Tahun 1988, sebagai panduan operasional BPN, pimpinan lembaga ini kemudian mengeluarkan SK No. 11/KBPN/1988 joKeputusan Kepala BPN Nomor 1 Tahun 1989 tentang Organisasi Dan Tata Kerja BPN Di Provinsi Dan Kabupaten/Kotamadya. Secara normatif BPN adalah satu-satunya lembaga atau institusi di Indonesia yang diberikan kewenangan untuk mengemban amanat dalam mengelolah bidang pertanahan, sesuai dengan Perpres Nomor 10 Tahun 2006 tentang Badan Pertanahan Nasional yang menyatakan bahwa BPN melaksanakan tugas dibidang pertanahan secara nasional regional dan sektoral.

Melalui proses yang sama, pemerintah juga telah memperkuat peran dan posisi BPN dengan membentuk Deputi V yang secara khusus mengkaji dan menyelesaikan sengketa dan konflik pertanahan. Sebagaimana dalam peraturan Kepala BPN-RI Nomor 3 Tahun 2006 tentang Organisasi dan Tata Kerja BPN-RI, pengkajian dan penanganan sengketa dan konflik pertanahan merupakan bidang Deputi V yang membawahi:

a. Direktorat konflik pertanahan

b. Direktorat sengketa pertanahan

c. Direktorat perkara pertanahan

Badan Pertanahan Nasional selalu mengupayakan solusi penyelesaian sengketa pertanahan dengan berdasarkan peraturan perundangan yang berlaku dengan memperhatikan rasa keadilan dan menghormati hak dan kewajiban masing-masing pihak. Langkah-langkah penyelesaian sengketa yang mereka atau pihak BPN tempuh adalah musyawarah. Begitu juga dalam sengketa sertifikat ganda, BPN juga berwenang melakukan negosiasi, mediasi dan fasilitasi terhadap pihak-pihak yang bersengketa dan menggagas suatu kesepakatan di antara para pihak. dan Kantor wilayah BPN yaitu di Provinsi dan Kabupaten/Kotamadya, hanya bisa sampai pada putusan penyelesaian masalah, sedangkan tindak lanjut administrasi pertanahan tetap dilakukan BPN.

Sering terjadinya sengketa tanah, maka untuk meminimalkan terjadinya sengketa pertanahan dalam hal ini sertifikat ganda, maka BPN, khususnya BPN Kota Yogyakarta yang dianggap sebagai pelayan masyarakat, terutama masyarakat di wilayah Kota Yogyakarta antara lain adalah:

a. Menelaah dan mengelolah data untuk menyelesaikan perkara di bidang pertanahan. 
b. Menampung gugatan-gugatan, menyiapkan bahan memori jawaban, menyiapkan memori banding memori/kontra memori kasasi, Memori/kontra memori peninjauan kasasi atas perkara yang diajukanmelalui peradilan terhadap perorangan dan badan hukum yang merugikan negara. Mengumpulkan data masalah dan sengketa pertanahan.

c. Menelaah dan menyiapkan konsep keputusan mengenai Penyelesaian sengketa atas tanah.

d. Menelaah dan menyiapkan konsep keputusan pembatalan hak atas tanah yang cacat administrasi dan berdasarkan kekuatan putusan peradilan.

e. Mendokumentasi. ${ }^{6}$

Badan Pertanahan Nasional Kota Yogyakarta memiliki mekanisme tertentu dalam menangani dan menyelesaikan perkara atau sengketa pertanahan dalam hal ini termasuk juga sengketa sertifikat ganda yaitu:

a. Sengketa tanah biasanya diketahui oleh BPN dari pengaduan.

b. Pengaduan ditindaklanjuti dengan mengidentifikasikan masalah, apakah unsur masalah merupakan kewenangan BPN atau bukan.

c. Jika memang kewenangannya, maka BPN meneliti masalah untuk membuktikan kebenaran pengaduan serta menentukan apakah pengaduan beralasan untuk diproses lebih lanjut.

d. Hasil penelitian perlu ditindaklanjuti dengan pemeriksaan data fisik administrasi serta yuridis, maka kepala kantor dapat mengambil langkah berupa pencegahan mutasi (status quo).

e. Permasalahan bersifat strategis, maka diperlukan pembentukan beberapa unit kerja. Jika bersifat politis, sosial, dan ekonomis maka tim melibatkan institusi berupa DPR atau DPRD, departemen dalam negeri, pemerintah daerah terkait.

f. Tim akan menyusun laporan hasil penelitian untuk menjadi bahan rekomendasi penyelesaian masalah. ${ }^{7}$

Penyelesaian terhadap sengketa pertanahan bukan hanya dilakukan oleh Badan Pertanahan Nasional tetapi juga bisa diselesaikan oleh lembaga Peradilan Umum dan Peradilan Tata Usaha Negara. Jika diperadilan umum lebih menitikberatkan kepada halhal mengenai perdata dan pidana dalam sengketa pertanahan, lain halnya dengan peradilan tata usaha negara yang menyelesaikan sengketa pertanahan berkaitan dengan surat keputusan yang dikeluarkan oleh Badan Pertanahan Nasional atau pejabat daerah lainnya yang berkaitan dengan tanah.

\footnotetext{
${ }^{6}$ Hasil wawancara dengan Mokhamad Munakam, A.Ptnh, Jum'at 25 Oktober 2019, 09.56 WIB

${ }^{7}$ Ibid.
} 
Pada saat ini, kebanyakan sengketa pertanahan dalam hal ini sertifikat ganda diselesaikan melalui 3 (tiga) cara, yaitu:

a. Penyelesaian secara langsung oleh pihak dengan musyawarah.

Dasar musyawarah untuk mufakat tersirat dalam pancasila sebagai dasar kehidupan bermasyarakat Indonesia dan dalam UUD 1945. Musyawarah dilakukan diluar pengadilan dengan atau tanpa mediator. Mediator biasanya dari pihak-pihak yang memiliki pengaruh misalnya Kepala Desa/Lurah, ketua adat serta pastinya Badan Pertanahan Nasional. Dalam penyelesaian sengketa pertanahan lewat musyawarah,satu syaratnya adalah bahwa sengketa tersebut bukan berupa penentuan tentang kepemilikan atas tanah yang dapat memberikan hak atau menghilangkan hak seseorang terhadap tanah sengketa, dan diantara pihak bersengketa memiliki kekebaratan yang cukup erat serta masih menganut hukum adat setempat. ${ }^{8}$

b. Arbitrase dan alternatif penyelesaian sengketa.

Arbitrase adalah penyelesaian perkara oleh seorang atau beberapa arbiter (hakim) yang diangkat berdasarkankesepakatan/persetujuan para pihak dan disepakati bahwa putusan yang diambil bersifat mengikat dan final. Persyaratan utama yang harus dilakukan untuk dapat mempergunakan arbitrase sebagai penyelesaian sengketa adalah adanya kesepakatan yang dibuat dalam bentuk tertulis dan disetujui oleh para pihak. Jika telah tertulis suatu klausula arbitrase dalam kontrak atau suatu perjanjian arbitrase, dan pihak lain menghendaki menyelesaikan masalah hukumnya ke pengadilan, maka proses pengadilan harus ditunda sampai prosesarbitrase tersebut diselesaikan dalam lembaga arbitrase. Dengan demikian pengadilan harus dan wajib mengakui serta menghormati wewenang dan fungsi arbiter. ${ }^{9}$

c. Penyelesaian sengketa melalui badan peradilan.

Sesuai dengan peraturan yang berlaku di Indonesia, pada umumnya penyelesaian sengketa pertanahan yang terkait sengketa kepemilikan diserahkan ke peradilan umum, terhadap sengketa keputusan Badan Pertanahan Nasional melalui Pengadilan Negri atau Pengadilan Tata Usaha Negara dan sengketa menyangkut tanah wakaf diajukan ke Pengadilan Agama. ${ }^{10}$

Penyelesaikan sengketa pertanahan dalam sertifikat tanah ganda di Kota Yogyakarta, prosedur yang ditempuh dalam penyelesaian sengketa pertanahan selalu melalui mekanisme mediasi oleh BPN dimulai adanya Pihak penggugat melaporkan gugatannya dikantor BPN.

Penanganan masalah pertanahan melalui lembaga mediasi oleh BPN biasanya didasarkan dua prinsip utama, yaitu:

\footnotetext{
${ }^{8}$ Ibid.

${ }^{9}$ Ibid.

${ }^{10}$ Ibid.
} 
a. Kebenaran-kebenaran formal dari fakta-fakta yang mendasari permasalahan yang bersangkutan.

b. Keinginan yang bebas dari para pihak yang bersengketa terhadap objek yang disengketakan. $^{11}$

BPN sebagai mediator mempunyai peran membantu para pihak dalam memahami pandangan masing-masing dan membantu mencari hal-hal yang dianggap penting bagi mereka. Mediator mempermudah pertukaran informasi, mendorong diskusi mengenai perbedaan-perbedaan kepentingan, persepsi, penafsiran terhadap situasi dan persoalanpersoalan dan mengatur pengungkapan emosi. Hal ini sesuai dengan peran mediator membantu para pihak memprioritaskan persoalan-persoalan dan menitikberatkan pembahasan mengenai tujuan dan kepentingan umum. Mediator akan sering bertemu dengan para pihak secara pribadi. Sebagai wadah informasi antara para pihak, mediator akan mempunyai lebih banyak informasi mengenai sengketa dan persoalan-persoalan dibandingkan para pihak dan akan mampu menentukan apakah terdapat dasar-dasar bagi terwujudnya suatu kesepakatan.

Suatu perjanjian perdamaian yang telah disepakati oleh para pihak yang bersengketa melalui proses mediasi, kemudian hasil akhir kesepakatan perjanjian perdamaian berikut notulensi dari proses mediasi yang dipandu oleh mediator tersebut dicantumkan dalam bentuk tertulis. Kemudian atas kesepakatan para pihak dan mediator hasil perjanjian tersebut dibuat dalam bentuk akta otentik melalui Notaris. Sebagai akta otentik kesepakatan perjanjian perdamaian yang merupakan hasil mediasi tersebut dibuat kembali dalam bentuk tertentu sebagai akta notariil sebagaimana apa yang terjadi dalam proses mediasi tersebut dalam bentuk tertulis (notulensi maupun hasil kesepakatan yang telah dicapai), artinya segala sesuatu yang diterangkan atau diceritakan (dalam kasus ini dalam bentuk tertulis sebagai hasil mediasi antara para pihak dibantu mediator) oleh pihak yang sengaja datang kepada Notaris.

Akta otentik yang dibuat tersebut memenuhi ketentuan-ketentuan bahwa akta tersebut dibuat oleh notaris berdasarkan keterangan para pihak yang sengaja datang menghadap kepada Notaris (dalam hal ini para pihak yang bersengketa dan mediator) dan berisikan suatu cerita (yang berupa notulensi dari rangkaian proses mediasi hingga pada kesepakatan para pihak). Kedatangan para pihak yang bersengketa beserta mediatornya sengaja menghadap kepada Notaris sebagai pejabat umum untuk membuat jadi akta otentik rangkaian proses mediasi dan hasilnya tersebut menunjukkan bahwa akta yang dibuat nantinya digolongkan ke dalam relaas acte. Dalam akta tersebut pihakpihak yang terlibat dalam suatu sengketa telah setuju untuk menyelesaikan sengketa di luar pengadilan dan telah berhasil mencapai suatu kesepakatan tertentu melalui mediasi, kemudian mereka datang ke Notaris untuk membuat suatu perjanjian perdamaian yang dituangkan dalam bentuk akta otentik.

${ }^{11}$ Ibid. 


\subsection{Faktor-Faktor Yang Menghambat Dalam Penyelesaian Sertipikat Hak Atas Tanah Ganda}

Berdasarkan hasil penelitian yang telah penulis lakukan, ada beberapa kendala yang terjadi dalam proses mediasi penyelesaian sengketa tanah, antara lain:

a. Kurangnya Mediator dalam Sengketa Tanah

Hasil penelitian yang dilakukan oleh penulis menunjukkan bahwa tidak ada mediator profesional yang memiliki kekhususan dalam penyelesaian masalah-masalah sengketa tanah, akibatnya setiap sengketa tanah yang para pihaknya sepakat untuk melakukan mediasi memilih Kantor Pertanahan Kabupaten/Kota sebagai mediator. ${ }^{12}$

\section{b. Sertifikasi Mediator}

Penanganan sengketa pertanahan merupakan tugas pokok dan fungsi dari Seksi Penanganan Sengketa dan Konflik Pertanahan yang menurut narasumber penelitian pada Kantor Badan Pertanahan Nasional Kota Yogyakarta pada seksi-seksi tersebut di masing-masing Kantor Pertanahan Kabupaten/Kota belum ada yang memiliki sertifikasi sebagai mediator berlisensi. ${ }^{13}$

c. Kenetralan BPN sebagai Mediator

Narasumber yang ditemui di Kantor Badan Pertanahan Nasional Kota Yogyakarta menyebutkan netralitas BPN sebagai mediator sering dipermasalahkan karena seringkali sengketa tanah yang terjadi antara para pihak di dalamnya melibatkan produk hukum yang dibuat oleh BPN. ${ }^{14}$

Guna menghadapi kendala dalam proses mediasi penyelesaian sengketa tanah, maka solusi yang didapatkan berdasarkan hasil penelitian adalah:

a. Mediasi dalam menyelesaikan sengketa pertanahan merupakan upaya yang paling tepat dan cepat untuk menyelesaikan permasalahan.

b. Dalam kondisi tidak adanya mediator profesional yang memiliki kepakaran di bidang sengketa tanah BPN dapat menutup kekosongan tersebut melalui pejabat/stafnya yang ditugaskan untuk menjadi mediator dalam proses mediasi yang dimintakan oleh para pihak ke Kantor Pertanahan. Mediator dari BPN tentunya memiliki kelebihan penguasaan permasalahan dan dapat mengakses riwayat permasalahan tanah dengan mudah lewat Kantor Pertanahan.

c. Tidak adanya lisensi yang dimiliki oleh pejabat/staf BPN yang ditunjuk menjadi mediator dalam sebuah mediasi sengketa tanah dapat diatasi dengan menambah kuota peserta diklat mediasi yang diselenggarakan oleh Pusat Pendidikan dan Pelatihan BPN RI.

\footnotetext{
${ }^{12}$ Ibid.

13 Ibid.

14 Ibid.
} 
d. Kenetralan BPN sebagai mediator karena di dalam sengketa para pihak seringkali terlibat produk hukum yang dibuat oleh BPN dilakukana solusi dengan menunjuk pejabat/staf yang tidak memiliki riwayat tidak terlibat dalam pembuatan produk hukum yang sedang disengketakan oleh para pihak. ${ }^{15}$

\section{Simpulan}

Penyelesaian sertipikat hak atas tanah ganda di Kota Yogyakarta dilakukan dengan cara penyelesaian secara langsung oleh pihak dengan musyawarah, arbitrase dan alternatif penyelesaian sengketa dan penyelesaian sengketa melalui badan peradilan. Faktor-faktor yang menghambat dalam penyelesaian sertipikat hak atas tanah ganda di Kota Yogyakarta antara lain kurangnya Mediator dalam Sengketa Tanah, pada Kantor Badan Pertanahan Nasional Kota Yogyakarta pada seksi-seksi tersebut di masingmasing Kantor Pertanahan Kabupaten/Kota belum ada yang memiliki sertifikasi sebagai mediator berlisensi, dan netralitas BPN sebagai mediator sering dipermasalahkan karena seringkali sengketa tanah yang terjadi antara para pihak di dalamnya melibatkan produk hukum yang dibuat oleh BPN.

Dari simpulan yang elah di sampaikan ada sedikit hal yang masih membutuhkan perhatian yaitu 1) dalam hal ini BPN hendaknya dapat membuat struktur baru yang dapat dipercaya kenetralannya dengan posisi semacam inspektorat untuk mempercepat penyelesaian sengketa tanah melalui jalur di luar pengadilan, terutama mediasi, 2) diharapkan para pihak menyadari bahwa penyelesaian sengketa tanah melalui mediasi merupakan cara penyelesaiaan guna menampung kepentingan semua pihak, sehingga tidak hanya memperhatikan kepentingan pribadi.

\section{Daftar Pustaka}

\section{Buku dan Jurnal}

A.P. Parlindungan, Hilangnya Hak-hak Atas Tanah, CV. Mandar Maju, Bandung, 1999.

Ali Achmad Chomzah, Hukum Pertanahan; Pemberian Hak Atas Tanah Negara, Sertipikat Dan Permasalahan, Prestasi Pustaka, Jakarta, 2002.

Eddy Ruchiyat, Sistem Pendaftaran Tanah Sebelum dan Sesudah Berlakunya UUPA, Armico, Bandung, 1984.

Endriatmo Soetarto dan Moh. Shohibudin, "Menegaskan Kembali Keharusan Reforma Agraria sebagai Basis Pembangunan Pertanian dan Pedesaan (Agenda untuk Pemerintahan 2004-2009)", Jurnal Pembaruan Desa dan Agraria, Volume 01/Tahun I/, Progam Studi Sosiologi Pedesaaan IPB-Pusat Kajian Agraria, Bogor, 2004.

\footnotetext{
${ }^{15}$ Ibid.
} 
Kartasaputra, Masalah Pertanahan di Indonesia, Rineka Cipta, Jakarta, 2005.

N.E. Algra, H.R.W. Gokkel dkk, dalam Habib Ajie, 2004, "Penggerogotan Wewenang Notaris Sebagai Pejabat Umum"., Renvoi, Nomor 04, Th. II, 3 September.

Ronny Hanitijo Soemitro, Metodologi Penelitian Hukum, Ghalia Indonesia, Jakarta, 1985.

Wawan Setiawan, "Sikap Profesionalisme Notaris Dalam Pembuatan Akta Otentik", Media Notariat, Edisi Mei-Juni, 2004.

Yasardin, "Mediasi di Pengadilan Agama: Upaya Pelaksanaan SEMA No. 1 Tahun 2002” Mimbar Hukum, No. 63.

\section{Perundang-Undangan}

Undang-Undang Dasar Negara Republik Indonesia Tahun 1945.

Kitab Undang-Undang Hukum Perdata.

Undang-undang Nomor 5 Tahun 1960 tentang Pokok-pokok Agraria.

Undang-Undang Nomor 51 Tahun 2009 tentang Peradilan Tata Usaha Negara.

Undang-Undang Nomor 30 Tahun 2004 tentang Jabatan Notaris.

Peraturan Pemerintah Nomor 24 Tahun 1997 tentang Pendaftaran Tanah.

Peraturan Mahkamah Agung Nomor 1 Tahun 2016, tentang Prosedur Mediasi di Pengadilan.

\section{Wawancara}

Bapak Mokhamad Munakam, A. Ptnh. Kepala Kantor Badan Pertanahan Nasional Yogyakarta. Dilakukan pada Jum'at, 25 Oktober 2019. Pukul 09.56 WIB.

\section{Lain-lain}

Badan Pertanahan Nasional, Pengarahan Direktur Pengadaan Tanah Instansi Pemerintah pada Rapat Konsultasi Teknis Para Kepala Bidang Hak-Hak Atas Tanah Seluruh Indonesia, Jakarta, 15 Juli 2003. 